\title{
Academic Status: Who Wants It?
}

A survey conducted among academic librarians to determine their reaction to the concept of faculty status as expressed by the ACRL Standards showed a general endorsement of these standards by those librarians with advanced educational training, with ALA/ACRL membership, and with experience in public or administrative service.

\begin{abstract}
A veritr ues to be an issue of great concern. This concern was expressed recently by the membership of the Association of College and Research Libraries (ACRL) at the 1971 annual convention of the American Library Association. At that meeting the set of Standards for Faculty Status for College and University Librarians, which had been proposed in 1969 by the Committee on Academic Status of ACRL, was modified and approved by the membership of the national association. ${ }^{1}$

To implement these Standards, ACRL has pledged to
\end{abstract}

Investigate all violations of these standards which are reported by members of the Association of College and Research Libraries [and to] invoke the following sanctions against institutions of higher education which are found, after such investigation, to be in violation of any or all of these standards:

a. Publicize the violation and the institution concerned in CRL News and other appropriate publications.

b. Refuse to accept advertisements

Ms. Hyman is a health sciences librarian, SUNY, Buffalo. Dr. Schlachter is assistant professor at the Library School, University of Southern California, Los Angeles.

472 / in any ALA publication for positions at that institution.

c. Discourage its members from accepting employment at that institution, through notices in its publication and other means. ${ }^{2}$

Since ACRL is proposing to represent academic librarians, it should be determined whether academic librarians not only support the concept of faculty status but agree on the rights, privileges, and responsibilities which should accompany such status. Prior to the June convention, the Proposed Standards for Faculty Status, as drawn up by the ad hoc Committee on Academic Status, were published in College and Research Libraries News and opinions were solicited from the membership. ${ }^{3}$ Although arguments pro and con were received and published in subsequent issues of the journal, most represented the views of library or department heads. ${ }^{4}$ Similarly, E. J. Josey's study of New York academic librarians' reactions to the Proposed Standards was restricted to administrators of public contact departments. ${ }^{5}$ It cannot be assumed that library heads are speaking for their staff members in urging extension of academic status. Rank-and-file as well as administrative librarians in all departments of the library would be affected by changes in university policies resulting from implementation of the Stan- 
dards, their attitudes should also be known and considered.

In order to determine the reaction of all types of academic librarians to the specific provisions of the adopted Standards, a questionnaire was sent in March 1972 to a sample of full-time professional librarians working in private and public institutions of higher learning in southern California. For the purposes of the study "academic" and "faculty" status were used as synonymous terms and both were defined in terms of the Standards adopted by the ACRL.

\section{Population and Sample}

The population for the study consisted of the full-time professional members of the library staffs of all private and public junior colleges, colleges, and universities in the ten counties of southern California, as listed in the 1969-70 edition of the Accredited Institutions of Higher Education. ${ }^{6}$ All types of professional positions and all ranks of the library hierarchy were represented. Professional librarians were defined as:

... employees doing work that requires training and skill in the theoretical or scientific aspects of library work, as distinct from its mechanical aspect.7

From this population a stratified random sample of professional librarians employed in various types of academic institutions was selected. All 100 libraries were stratified according to the highest degree granted by their institution (A.A., B.A., M.A., and Ph.D.) and a random sample of 30 academic institutions was chosen. The names of all full-time professional librarians were then requested from the directors of their respective libraries. Twenty-eight academic libraries responded and 216 full-time professional librarians in these libraries were sent a survey questionnaire. A follow-up letter and another copy of the questionnaire were mailed two weeks later to those individuals who did not respond to the initial letter. Approximately 81 percent (174 librarians) returned usable questionnaires.

\section{QuestionNaIRE}

The first part of the questionnaire measured the librarians' attitudes toward academic status. Respondents were asked to indicate on a five-point rating scale (ranging from "strongly agree" to "strongly disagree") their reactions to twelve statements taken from the adopted Standards for Faculty Status for College and University Librarians (nos. 112 ) and to four statements (nos. 13-16) designed to identify the librarians' opinions on academic status in general (see Table 2).

The second part of the questionnaire identified personal, educational, occupational, and associational characteristics of the sample librarians to be used in analyzing their attitudinal responses (see Table 1).

\section{Findings}

Demographic data. It was found that, in general, the respondents were female (57 percent), nearing middle age (the median was just over forty years), married (57 percent), and had earned as their highest degree the first professional degree in librarianship (56 percent). Most were currently employed in public service positions ( 50 percent), had some formal administrative rank (nearly 70 percent), and had worked in that position less than five years (58 percent). Although over half of the southern California librarians belonged to their state professional association, only one-third were members of ACRL or ALA.

Interest in academic status. Overall, a high level of support was found both for the concept of academic status for librarians and for the specific rights, privileges, and responsibilities spelled 
TABLE 1

Percentage Distribution of Demographic Data For SOUTHERn CaLIFornia PARTICIPANTS $\mathrm{N}=174$

\begin{tabular}{|c|c|}
\hline Demographic data & $\begin{array}{l}\text { So. Calif. } \\
\text { librarians }\end{array}$ \\
\hline \multicolumn{2}{|l|}{ PERSONAL } \\
\hline \\
\hline Male & 43 \\
\hline Female & 57 \\
\hline \multicolumn{2}{|l|}{ Age } \\
\hline Under 25 & 4 \\
\hline $25-34$ & 32 \\
\hline $35-44$ & 25 \\
\hline $45-54$ & 21 \\
\hline 55 or older & 18 \\
\hline \multicolumn{2}{|l|}{ Marital status } \\
\hline \multicolumn{2}{|l|}{ Single (widowed/divorced/ } \\
\hline $\begin{array}{l}\text { separated) } \\
\text { Married }\end{array}$ & $\begin{array}{l}43 \\
57\end{array}$ \\
\hline \multicolumn{2}{|l|}{ EDUCATIONAL } \\
\hline \multicolumn{2}{|l|}{ Highest degree received } \\
\hline Less than a master's & 7 \\
\hline Subject master's only & 8 \\
\hline Bachelor's or Master's in L.S. & 56 \\
\hline Subject master's + Master's or & \\
\hline Bachelor's in L.S. & 21 \\
\hline $\begin{array}{l}\text { Specialist/6th year Master's/Ph.D. } \\
\text { OCCUPATIONAL }\end{array}$ & 8 \\
\hline \multicolumn{2}{|l|}{ OCCUPATIONAL } \\
\hline $\begin{array}{l}\text { Public services } \\
\text { Puich }\end{array}$ & 38 \\
\hline Technical services & 27 \\
\hline Administrative & 35 \\
\hline \multicolumn{2}{|l|}{ Rank in library hierarchy } \\
\hline Chief librarian or director & 12 \\
\hline Associate/assistant librarian & 24 \\
\hline \multicolumn{2}{|l|}{ Department or division head } \\
\hline school, or departmental library) & 34 \\
\hline Other professional assistant & 30 \\
\hline \multicolumn{2}{|l|}{ Years in present job } \\
\hline Less than 5 & 58 \\
\hline $5-10$ & \\
\hline $11-20$ & 11 \\
\hline & \\
\hline \multirow{2}{*}{\multicolumn{2}{|c|}{$\begin{array}{l}\text { ASSOCIATIONAL } \\
\text { Professional association membership }\end{array}$}} \\
\hline & \\
\hline State professional society & 57 \\
\hline \multicolumn{2}{|l|}{$\begin{array}{l}\text { American Library Association/ } \\
\text { Association of College and }\end{array}$} \\
\hline Research Libraries & 32 \\
\hline \multicolumn{2}{|l|}{ American Association of University } \\
\hline Professors & 11 \\
\hline None of these & 33 \\
\hline
\end{tabular}

- Does not total 100 percent because respondents could belong to more than one professional association.

out in the Standards. The range of agreement for the sixteen statements representing these ideas was from 62 to 97 percent, as shown in Table 2. Great- est agreement was expressed for increased responsibilities (no. 1), salaries proportionate to education and experience (no. 5), and protection of academic freedom (no. 12).

Interestingly, the three statements which showed the least amount of agreement are the ones that generally stand at the heart of any faculty status program. Only 60 percent of the participants agreed that their work could be considered teaching (no. 16), that they should have the same titles, ranks, and steps as other faculty (no. 9), or that the prestige of professional librarians would be enhanced if academic librarians were accepted as co-equals with faculty members (no. 14). Thus, although the majority of the surveyed librarians supported the Standards in general, there was greater agreement with statements defining specific rights and privileges than with those dealing with the concept of faculty status.

Overall, the findings in this section revealed a less enthusiastic endorsement of faculty status than Josey reported in his study of New York academic librarians. Josey, however, studied only those librarians who worked as administrators in public contact departments-librarians who would probably be more receptive to faculty status than academic librarians in general. In the present study librarians working in administrative capacities and in public contact work were found to be more supportive of faculty status than technical services librarians.

Relationship of personal, educational, occupational, and associational factors with interest in faculty status. Although the academic librarians responded favorably as a group to both the concept of academic status and the Standards governing such status, some librarians dissented. To identify those factors (the variates) related to the librarians' reaction to faculty status (criterion 
TABLE 2

Percentage Distribution

Of Academic Librarians' Attitude Toward Academic Status

$\mathrm{N}=174$

\begin{tabular}{|c|c|c|c|}
\hline Statement \# & Agree & Undecided & Disagree \\
\hline $\begin{array}{l}\text { 1. Each librarian should be assigned general responsibilities } \\
\text { within his particular area of competence. He should have } \\
\text { maximum possible latitude in fulfilling these responsibilities. }\end{array}$ & 97 & 1 & 2 \\
\hline $\begin{array}{l}\text { 5. The salary scale for librarians should be the same as that } \\
\text { for other academic categories with equivalent education } \\
\text { and experience. }\end{array}$ & 97 & 1 & 2 \\
\hline $\begin{array}{l}\text { 11. Librarians should have access to funding for research projects } \\
\text { on the same basis as other faculty. }\end{array}$ & 95 & 2 & 3 \\
\hline $\begin{array}{l}\text { 12. Librarians in colleges and universities must have the } \\
\text { protection of academic freedom. Library resources and } \\
\text { the professional judgment of librarians must not be } \\
\text { subject to censorship. }\end{array}$ & 94 & 4 & 2 \\
\hline $\begin{array}{l}\text { 10. Sabbatical and other research leaves should be available } \\
\text { to librarians on the same basis, and with the same } \\
\text { requirements as they are available to other faculty. }\end{array}$ & 93 & 4 & 3 \\
\hline $\begin{array}{l}\text { 7. Librarians should be covered by tenure provisions the same } \\
\text { as those of other faculty. In the pretenure period, librarians } \\
\text { should be covered by written contracts or agreements } \\
\text { the same as those of other faculty. }\end{array}$ & 92 & 4 & 4 \\
\hline $\begin{array}{l}\text { 4. Librarians should be eligible for membership in the academic } \\
\text { senate or equivalent body at their college or university } \\
\text { on the same basis as other faculty. }\end{array}$ & 91 & 5 & 4 \\
\hline $\begin{array}{l}\text { 8. Librarians should be promoted through ranks and steps on } \\
\text { the basis of their academic proficiency and professional } \\
\text { effectiveness, by means of a peer review system similar to } \\
\text { that used by other faculty. }\end{array}$ & 87 & 8 & 5 \\
\hline $\begin{array}{l}\text { 6. Librarians should normally be appointed for the academic } \\
\text { year. If a librarian is expected to work through the } \\
\text { summer session, his salary scale should be adjusted } \\
\text { similarly to the summer session of other faculty at this } \\
\text { college or university. }\end{array}$ & 86 & 6 & 8 \\
\hline $\begin{array}{l}\text { 13. Complete equality with faculty is a desirable goal for all } \\
\text { professional librarians working in college and university } \\
\text { libraries. }\end{array}$ & 84 & 8 & 8 \\
\hline $\begin{array}{l}\text { 15. There are significant disadvantages to librarians who work } \\
\text { in universities or colleges that do not grant faculty status } \\
\text { to their professional librarians. }\end{array}$ & 83 & 11 & 6 \\
\hline $\begin{array}{l}\text { 3. College and university libraries should adopt an academic } \\
\text { form of governance. The librarians should form as a library } \\
\text { faculty whose role and authority is similar to that of the } \\
\text { faculties of a college, or of a school or department. }\end{array}$ & 73 & 16 & 11 \\
\hline $\begin{array}{l}\text { 2. The degree to which he has fulfilled his responsibilities } \\
\text { should be regularly and rigorously reviewed by appraisal by } \\
\text { a committee of peers who have access to all available } \\
\text { evidence. }\end{array}$ & 70 & 13 & 17 \\
\hline $\begin{array}{l}\text { 16. A major portion of your work time and energy is devoted } \\
\text { to activities that should be considered as teaching } \\
\text { through either direct or indirect contact with students. }\end{array}$ & 66 & 10 & 24 \\
\hline $\begin{array}{l}\text { 14. The prestige of professional librarians would not be } \\
\text { especially enhanced if college and university librarians } \\
\text { were accepted in all respects as co-equal with faculty } \\
\text { members. }\end{array}$ & 20 & 15 & 65 \\
\hline $\begin{array}{l}\text { 9. The librarian's promotion ladder should have the same } \\
\text { title, ranks, and steps as that of other faculty. }\end{array}$ & 63 & 18 & 19 \\
\hline
\end{tabular}


variable), a step-wise multiple regression analysis was run on the four statements (nos. 9, 14, 16, 2) which showed the least agreement (see Table 3 ).

At the .05 level two factors, age and professional association membership, entered as significant variates in the regression equation for equal titles and ranks for faculty and librarians (no. 9). Younger respondents were more likely to reject the concept of equal titles for librarians and faculty than were older participants. Also, respondents who did not belong to the ALA/ACRL were less likely to agree that "the librarian's promotion ladder should have the same titles, ranks, and steps as that of other faculty" than were members of the organizations.

Several variates (age, educational level, and type of library job held) correlated significantly with the librarians' reaction to the idea that "the prestige of professional librarians would not be especially enhanced if . . . librarians were accepted in all respects as coequals with faculty members (no. 14)." Younger librarians were more likely than older respondents to agree with the above statement. In addition, the less educated the respondents, the less likely they were to feel that faculty status could enhance the prestige of academic librarians. The same view was shared by technical services librarians, who were more likely than public services or administrative librarians to feel that faculty status would not result in a better image of academic librarians.

The type of job the surveyed librarians held and the number of years they had worked in that position significantly related to their view of the way academic librarians function. When all other factors were held constant, technical services librarians were less likely

TABLE 3

StEPWISE REgRession EQUations

For Librarians' Attitude Toward Faculty and Status and Significant Variates ${ }^{\circ}$ $\mathrm{N}=174$

\begin{tabular}{|c|c|c|c|c|c|c|c|c|}
\hline \multirow[b]{2}{*}{ 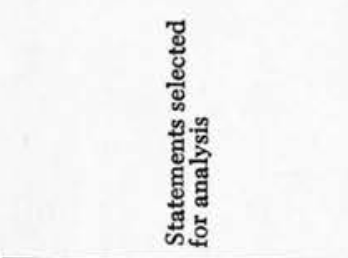 } & \multirow[b]{2}{*}{ 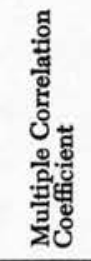 } & \multirow[b]{2}{*}{ 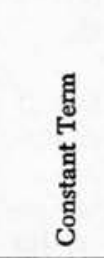 } & \multicolumn{6}{|c|}{ Variates } \\
\hline & & & 离 & ڤึ & 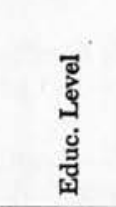 & 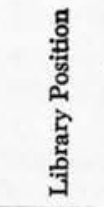 & 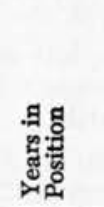 & 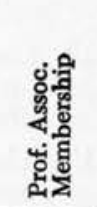 \\
\hline $\begin{array}{l}\text { Statement \# } 2^{\circ \circ} \\
\text { Regression coefficient } \\
\text { Standard error } \\
\text { F-value }\end{array}$ & .362 & .956 & $\begin{array}{r}.088 \\
.043 \\
4.201\end{array}$ & $\begin{array}{r}.540 \\
.178 \\
9.184\end{array}$ & $\begin{array}{r}.158 \\
.107 \\
2.195\end{array}$ & - & - & - \\
\hline $\begin{array}{l}\text { Statement \#16 } \\
\text { Regression coefficient } \\
\text { Standard error } \\
\text { F-value }\end{array}$ & .330 & .992 & - & - & - & $\begin{array}{r}.401 \\
.200 \\
4.425\end{array}$ & $\begin{array}{r}.003 \\
.000 \\
6.054\end{array}$ & - \\
\hline $\begin{array}{l}\text { Statement \#14 } \\
\text { Regression coefficient } \\
\text { Standard error } \\
\text { F-value }\end{array}$ & .314 & 1.038 & $\begin{array}{r}.125 \\
.044 \\
8.045\end{array}$ & - & $\begin{array}{r}.331 \\
.104 \\
10.198\end{array}$ & $\begin{array}{r}.417 \\
.210 \\
3.925\end{array}$ & - & - \\
\hline $\begin{array}{l}\text { Statement \#9 } \\
\text { Regression coefficient } \\
\text { Standard error } \\
\text { F-value }\end{array}$ & .288 & 1.754 & $\begin{array}{r}-.075 \\
.044 \\
2.864\end{array}$ & - & - & - & - & $\begin{array}{r}.916 \\
.328 \\
7.971\end{array}$ \\
\hline
\end{tabular}

- Significant at the $a=.05$ level or better.

$\bullet$ See Table 2 for specific wording of statements. 
to support the view that academic librarians function as teachers (no. 16) than were public services or administrative library employees. In addition, the less time librarians had held their present jobs, the less they supported the idea that librarians operate as teachers.

Age, sex, and educational level proved to be significant predictors of those librarians who opposed the use of peer groups to appraise librarians' performance (no. 2). Females were more likely to oppose peer appraisal than were younger librarians. Those librarians who did not support peer evaluation of work performance could also be identified by educational level. The more advanced the degree earned, the more likely the librarian was to oppose evaluation by a peer group.

\section{SUMMARY}

Southern California academic librarians generally support both the concept of academic status and the Standards which have been adopted by the ACRL to achieve such status. Statements dealing with specific rights and privileges, however, were more enthusiastically approved than those presenting the philosophy and concepts of academic status. Even the controversial proposal of peer evaluation received greater support from the surveyed librarians than the view that librarians operate as teachers.

Certain factors related significantly to the librarians' views on selected aspects of academic status.

Age: While older librarians were more likely than their younger colleagues to advocate faculty titles for librarians and to claim that faculty status would enhance their prestige, they were more likely to oppose the idea of peer appraisal of their work performance.

Sex: Females were more likely to oppose the idea of peer evaluation than were male librarians.

Educational level: The more ad- vanced the librarians' educational background, the more likely they were to support the importance of acceptance as equals with faculty members and the less likely they were to agree to the idea of peer appraisal.

Library position: Public services and administrative librarians were more likely than technical services librarians to feel that faculty status would enhance the librarians' prestige and to agree that librarians function as teachers.

Years in position: The longer librarians had held their present jobs, the more likely they were to support the view of librarians as teachers.

Professional association membership: Members of ALA/ACRL were more likely than nonmembers to agree that librarians should have the same rank and titles as faculty.

Thus, sampled librarians who were older, had advanced educational training, worked for an extended period of time in public service or administrative capacities and belonged to ALA/ACRL were more likely to support faculty status than those who did not share these characteristics. Interestingly, however, many of these same librarians did not support one practice of the Standards: peer evaluation of work performance. In particular, older female librarians with advanced educational training were less likely to support this practice than librarians who did not share these characteristics.

In general, however, the support the ACRL would need to continue its push for faculty status is definitely present among southern California librarians. Since these librarians are demographically similar to librarians located in other areas, it does not seem unreasonable to suggest that the findings in this study would hold true not only for southern California librarians, but for academic librarians in other geographical locations throughout the country. ${ }^{8}$ 


\section{REFERENCES}

1. "Standards for Faculty Status Approved," CRL News 32:217 (Sept. 1971).

2. "Standards for Faculty Status for College and Research Librarians," CRL News 32: 172 (June 1971).

3. "ACRL Academic Status Committee Proposes Standards for Librarians," CRL News 31:270 (Oct. 1970).

4. Robert M. Pierson, "The Proposed Standards for Faculty Status: A Dissenting Opinion," CRL News 32:121-25, 127 (May 1971); "Academic Status," CRL News 32:173-74 (June 1971).

5. E. J. Josey, "Full Faculty Status This Century," Library Journal 97:984-89 (15 March 1972).

6. Accredited Institutions of Higher Educa- tion, 1969-1970. (Washington, D.C.: Federation of Regional Accrediting Commission of Higher Education, 1969), p.7-17.

7. Anita Schiller, Characteristics of Professional Personnel in College and University Libraries (Washington, D.C.: U.S. Department of Health, Education and Welfare, 1969, Research Series No. 16), p.5.

8. See data taken from Gail Ann Schlachter, 'Professional Librarians' Attitudes toward Professional and Employee Associations as Revealed by Academic Librarians in Seven Midwestern States" (Ph.D. dissertation, Minneapolis, University of Minnesota, 1971, p.255-82), which reveals similar distribution of these characteristics for selected midwestern librarians. 